\title{
MINIREVIEW
}

\section{Glaucoma in Costa Rica. Initial approaches}

\author{
Gabriela Chavarría-Soley ${ }^{1,2}$, Bernd Rautenstrauss ${ }^{1}$ \& Jorge Azofeifa $2 *$ \\ Institut für Humangenetik, Friedrich-Alexander-Universität, Erlangen-Nürnberg, Germany. \\ Escuela de Biología and Instituto de Investigaciones en Salud (INISA), Universidad de Costa Rica. \\ Correspondence author: Jorge Azofeifa, Instituto de Investigaciones en Salud (INISA), Universidad de Costa Rica, \\ Ciudad Universitaria "Rodrigo Facio", San José, Costa Rica, Central America, Tel. (00506) 2243668, Fax (00506) 207 \\ 5130; azofeifa@biologia.ucr.ac.cr
}

Received 27-XI-2003. C Corrected 06-VIII-2004. Accepted 12-VIII-2004.

\begin{abstract}
Glaucoma is the second most frequent cause of irreversible blindness worldwide. Genetic factors have been implicated in the development of the disease. So far six loci (GLC1A-GLC1F) and two genes $(T I G R / M Y O C$ and $O P T N$ ) are involved in the development of juvenile (JOAG) and adult onset or chronic primary open angle glaucoma (COAG), while two loci (GLC3A,GLC3B) and one gene (CYP1B1) are known for primary congenital glaucoma (PCG). Here we summarize the results of the first genetic studies of glaucoma in Costa Rica. Nine families: 1 with JOAG, 1 with PCG and 7 with COAG were screened for mutations at the known genes. A 10 bp duplication, 1546-1555dupTCATGCCACC, at the CYP1B1 gene, causes, in homozygous state, glaucoma in the consanguineous PCG family. This mutation has been found in different countries and generates an early stop codon that termitates protein synthesis 140 amino acids earlier than the normal allele. In exon 1 of the TIGR/MYOC the innocuous Arg76Lys variant was found in two of the COAG families. In the OPTN gene two variants in the coding region (Thr34Thr, Met 98Lys) and 7 intronic changes were found in other Costa Rican glaucoma patients. One of the COAG families was chosen for a genome scan with 379 microsatellite markers and linkage analysis. LOD scores "suggestive" of linkage were obtained for several chromosomal regions. Evidence indicates that hereditary glaucoma in Costa Rica is highly heterogeneous and that further studies in the country will probably disclose some up to now unknown genes responsible for the disease. Rev. Biol. Trop. 52(3): 507-520. Epub 2004 Dic 15.
\end{abstract}

Key words: glaucoma, TIGR/MYOC, OPTN, CYP1B1, genome scan, linkage analysis.

Palabras clave: glaucoma, TIGR/MYOC, OPTN, CYP1B1, rastreo genómico, análisis de ligamiento.

Glaucoma is a clinically and genetically heterogeneous group of chronic eye diseases characterized by degeneration of the optic nerve head, a distinctive pattern of visual field loss, and a painless progression, usually associated with elevated intraocular pressure (Shields et al. 1996). Worldwide, it is the second most frequent cause of irreversible blindness in the age group of 40 years or older (Quigley 1996), and remarkably, Rodríguez et al. (2002) estimated that glaucoma was the main cause of bilateral blindness in a group of "Hispanics", aged 40 years and older, residing in USA.

The different kinds of glaucoma are classified according to their etiology (primary versus secondary), to the anatomy of the anterior chamber of the eye (open angle versus closed angle) and to the age of onset (congenital, juvenile, adult) (Shields 1996). Primary open angle glaucoma (POAG) is the most frequent kind in Western countries (Shingleton et al 1994), while in Orientals most cases are closed angle glaucomas (Lai et al 2001, Foster and Johnson 2001). Among the POAG, chronic open angle glaucoma (COAG) with an age of onset after the fourth decade of life, accounts for approximately half of all cases. The less frequent juvenile open angle glaucoma (JOAG) usually has a more severe phenotype with an age of onset between 3 and 30 years. 
The also rare primary congenital glaucoma (PCG), sometimes referred to as buphthalmos, is congenital or manifests during the first 3 years of age (Shields et al. 1996).

\section{EPIDEMIOLOGY AND GENETICS}

In general, epidemiological data for glaucoma are vague. Several authors have reported prevalence rates which are impossible to compare because of differences in diagnostic criteria, in the ages of onset and the ethnic affiliation of the subjects studied. Thus, reported prevalence figures from individuals with ages over 40 years range from $0.2 \%$ to $7 \%$, with the highest values always found in Blacks (Dielemans et al. 1994, Leske et al. 1994, Ekstrom 1996, Wensor et al. 1998, Buhrmann et al. 2000, Quigley 2001, Racette et al. 2003). Quigley et al. (2001) estimated the prevalence of glaucoma in 4774 Hispanic subjects living in USA. They found an intermediate value $(1.97 \%)$ between those reported for Caucasians and Afro-Americans. The age-specific prevalence in this population increased from $0.5 \%$ in the age group 41 to 49 years to $12.63 \%$ in persons older than 80 years.

Regarding incidence there is an even smaller number of studies, which, in addition, offer less reliability because their values have been estimated indirectly from the prevalences. A remarkable exception is the Barbados Eye Study where 3000 subjects of Subsaharan African ancestry older than 40 years and without a previous diagnosis of glaucoma were prospectively followed up during a period of 4 years. Incidence was estimated to be $0.55 \%$ per year. The risk was especially high for older adults, exceeding $1 \%$ per year for the oldest age group (Leske et al. 2001).

Incidence of open-angle glaucoma has been associated with several risk factors (Le 2003). Prevalence of the disease clearly increases with age (Leske et al. 1994, Klaver et al. 1998, Leske et al. 2001, Quigley 2001, Le et al. 2003, Lee et al. 2003). However, controversy exists for the role of elevated intraocular pressure as a risk factor, mainly because the levels of intraocular pressure at which a person develops disease vary greatly. Le et al. (2003) found no significant risk for intraocular pressure higher than $21 \mathrm{~mm} \mathrm{Hg}$, often considered the threshold value at which risk increases (Shingleton et al. 1994), however they did find a higher mean intraocular pressure in glaucoma subjects than in controls. Genetic predisposition has been recognized for a long time as an important risk factor. Wolfs et al (1998) found that prevalence of glaucoma, enlarged cup-disc ratio (one of the first signs of glaucoma), and elevated intraocular pressure are much higher in siblings and offspring of patients with glaucoma than in relatives of controls and estimated that their lifetime risk of glaucoma was 10 times higher than that of their healthy controls. The authors also estimate that a genetic component may underlie in at least one sixth of all glaucoma cases in the general population. In the Barbados Family Study Nemesure et al. (2001) examined 1056 relatives from 207 open-angle glaucoma affected probands. Among them 10\% clearly had openangle glaucoma and $13 \%$ could be affected (i.e., individuals showed some symptoms like visual field loss or disc pathology but did not meet all the diagnostic criteria for glaucoma).

Besides the many sporadic cases, inheritance of the disease, especially the COAGs also shows great variation (Wiggs et al. 2000). In some families it conforms to Mendelian segregation ratios whereas in others it presents complex patterns, i.e., they only show aggregation of patients. Among the families with Mendelian inheritance, different modes of inheritance have been documented, but in most cases with COAG and JOAG the segregation is autosomal dominant, while PCG follows a recessive pattern of inheritance (Sarfarazi 1997). 


\section{GENOMIC REGIONS AND GENES IDENTIFIED}

Mapping efforts, mainly linkage analyses, have led to the discovery of genomic regions (loci) and genes responsible for glaucomas with Mendelian patterns of inheritance. To date 6 loci and 2 candidate genes have been identified for the autosomal dominantly inherited POAGs, 2 further loci and mutations in one gene were found for congenital glaucoma (Table 1).

\section{Myocilin (MYOC, GLC1A)}

Shortly after the identification of the first candidate gene for primary open angle glaucoma, the "trabecular meshwork inducible glucocorticoid response" (TIGR) gene, the gene Myocilin (MYOC), was isolated from cDNA from human retina (Stone et al. 1997), cloned, characterized, and shown to be identical to TIGR (Kubota et al. 1997, Polansky et al. 1997, Stone et al. 1997). Although more than 100 potentially disease causing mutations have been identified in the TIGR/MYOC gene and remarkably, most of them located in exon 3 (Human Gene Mutation Database Cardiff, HGMD), several large studies have shown that only 3 to $5 \%$ from POAG patients carry mutations in the MYOC (GLC1A) gene (MichelsRautenstrauss et al. 1998, Fingert et al. 1999, Kubota et al. 2000, Michels-Rautenstrauss et al. 2002).

TIGR/MYOC is expressed in the trabecular meshwork and its product, myocilin, is secreted into the aqueous humor. Very little to no myocilin was secreted in vitro from cells expressing five different mutant forms of $M Y O C$, and no mutant myocilin was detected in the aqueous humor of patients with the most common mutation, Gln368Stop (Jacobson et al. 2001). Apparently mutant myocilin, lacking the olfactomedin-like domain, is not correctly processed in the endoplasmic reticulum and accumulates into insoluble aggregates. The presence of increasing amounts of mutant protein induces a fraction of the soluble, native myocilin to move to the insoluble fraction (Caballero y Borras 2001). Interestingly, mice homozygous and heterozygous for a myocilin null mutation do not exhibit a pathological phenotype, indicating that a loss-of-function effect could not necessarily cause the glaucomatous phenotype in humans (Tamm 2002). For a comprehensive review of the pathobiology of MYOC refer to Tamm (2002).

TABLE 1

Chromosomal location and known genes for different types of primary glaucomas

\begin{tabular}{|c|c|c|c|c|c|c|}
\hline Type & Name & Locus & Inheritance & \#OMIM* & Gene & References \\
\hline$J O A G$ & GLC1A & $1 q 23-q 25$ & $\mathrm{AD}^{* *}$ & 601652 & MYOC & $\begin{array}{l}\text { Sheffield et al. 1993, Stone et al. } 1997 \text {, } \\
\text { Polansky et al. 1997, Kubota et al. } 1997\end{array}$ \\
\hline \multirow[t]{5}{*}{$C O A G$} & GLC1B & 2 cen-q13 & $\mathrm{AD}$ & 606689 & unknown & Stoilova et al. 1996 \\
\hline & GLC1C & $3 q 21-q 24$ & $\mathrm{AD}$ & 601682 & unknown & Wirtz et al. 1997, Kitsos et al. 2001 \\
\hline & GLC1D & $8 \mathrm{q} 23$ & $\mathrm{AD}$ & 602429 & unknown & Trifan et al. 1998 \\
\hline & GLC1E & 10p15-p14 & $\mathrm{AD}$ & 602432 & OPTN & Sarfarazi et al. 1998, Rezaie et al. 2002 \\
\hline & GLC1F & $7 \mathrm{q} 35-36$ & $\mathrm{AD}$ & 603383 & unknown & Wirtz et al. 1999 \\
\hline \multirow[t]{2}{*}{$P C G$} & GLC3A & $2 \mathrm{p} 21$ & $\mathrm{AR}^{* * *}$ & 601771 & CYP1B1 & $\begin{array}{c}\text { Sarfarazi et al. 1995, Stoilov et al. 1997, } \\
\text { Bejjani et al. } 1998\end{array}$ \\
\hline & GLC3B & $1 \mathrm{p} 36$ & $\mathrm{AR}$ & 600975 & unknown & Akarsu et al. 1996 \\
\hline
\end{tabular}




\section{Optineurin (OPTN, GLC1E)}

Linkage analysis of a single family with normal tension glaucoma (NTG) and patients with an age of onset between 23 and 65 years implicated a $21 \mathrm{cM}$ region (GLC1E) on chromosome 10p14-p15 (Sarfarazi et al. 1998). The OPTN gene, also known as FIP-2 (Li et al. 1998) and as NRP (Schwamborn et al. 2000), was later identified in this region (Rezaie et al. 2002). Optineurin interacts with huntingtin (Faber et al. 1998), with the transcription factor IIIA (Moreland et al. 2000) and with RAB8, a GTPase involved in membrane transport (Hattula and Peranen 2000). OPTN could belong to the tumor necrosis factor alpha (TNF-a) signal pathway and through loss of function due to mutation facilitate the induction of apoptosis (Li et al. 1998).

A missense mutation Glu50Lys was identified in the original family. Later, Rezaie et al. (2002) discovered four additional variants after screening 54 families with autosomal dominant COAG which had at least one member with normal tension. The authors found mutations in the OPTN gene in $16.7 \%$ from families with glaucoma presenting normal to moderately elevated intraocular pressure and considered a Met98Lys change in exon 5 as a "risk associated variant". However, subsequent studies with sporadic POAG patients have found this variant at very similar frequencies in patients and controls, lending doubt about the putative morbidity of the amino acid change. The frequency of OPTN mutations in these sporadic patients' groups is very low, ranging from $0 \%$ to $1.6 \%$ in studies in USA, England and China (Aung et al. 2003, Leung et al. 2003, Wiggs et al. 2003).

\section{Cytochrome P450 1B1 (CYP1B1, GLC3A)}

In PCG families from different ethnic groups with linkage to GLC3A several disease causing mutations were identified in the cytochrome P450 1B1 (CYP1B1) gene (Stoilov et al. 1997,1998, Bejjani et al. 1998), one of the more than 300 members of the P450 gene superfamily (Nebert et al. 1991, Sarfarazi 1997, Stoilov et al. 2001). Mutations in this gene seem to be the main cause of familial PCG cases (Sarfarazi and Stoilov 2000). More than 50 disease causing mutations have been described (Bejjani et al. 1998, Stoilov et al. 1998, Bejjani et al. 2000, MichelsRautenstrauss et al. 2001, Stoilov et al. 2002, Chavarría Soley et al. 2003), from which nearly $50 \%$ cause either a truncated protein, loss of the hem-binding domain coded in exon 3 , or the loss of highly conserved amino acids with important functions. CYPIBI is believed to have a role in the normal development and function of the anterior eye chamber (Sarfarazi and Stoilov 2000, Stoilov et al. 2001).

\section{Other loci}

Wiggs et al. (2000) employed a two-step affected-sib-pair (ASP) analysis with 113 ASPs with POAG from 41 families and obtained multipoint-lod-scores higher than 1 for seven loci and higher than 2 for five loci. From the previously known loci only GLC1B in chromosome 2 cen-q13 was confirmed, the rest of the regions with high scores were found for the first time in this study. A more recent study comprising 1327 individuals and 146 families (the Barbados family study of Open Angle Glaucoma) did not find any linkage to the $M Y O C$ locus, but gave some evidence for chromosomes 1, 2, 9, 10, 11 and 14 (Nemesure et al. 2003).

Summing up, the studies of familial glaucoma have disclosed a significant genetic heterogeneity. A good number of the genes responsible for glaucomas are still to be discovered. The genome wide scans performed so far have begun to identify several "interesting" regions, where a gene responsible for glaucoma could be located. This indicates that a considerable number of genes must be implicated in the delicate patterns of eye development and in the complexity of the regulatory mechanisms of eye homeostasis; the heterogeneity is thus explained if mutations at all these genes alter the normal ocular physiology. Therefore, 
from an evolutionary perspective it is not surprising to find not only ethnic-specific mutated genes and private glaucoma causing alleles but also alleles specific to geographic areas where human expansion has recently originated (and still originates) new populations. Interethnic admixture, breaking of isolates plus de novo mutation might have produced interesting combinations of susceptibility alleles for glaucoma, and other diseases, in these places, an evolutionary situation worth studying. The countries of the New World are among the ones where this possibility can be tested.

\section{GLAUCOMA IN COSTA RICA}

The study of glaucoma in Costa Rica began in the year 2000 as a result from an earlier cooperation between geneticists of the School of Biology and INISA, University of Costa Rica and of the Institute of Human Genetics from the Friedrich-Alexander University of Erlangen-Nuremberg, Germany. Its main goals are the genetic and molecular characterization of primary glaucomas in Costa Rica. Contact to the patients was possible thanks to the collaboration of ophthalmologists who were willing to participate in the project and who kept records of familial glaucoma. To consider a case as familial, there must be at least a second affected person in the family besides the propositus, and the disease must be present in at least two generations. A total of 9 families with glaucoma complied with these requirements; seven of them present COAG, one has JOAG and one has PCG. The age of onset in the COAG families varied from 40 to 70 years old, however a great concordance among the members of each family was the rule.

The patients were contacted and, after informed consent, pedigrees from the families were constructed and DNA was extracted from peripheral blood. DNA extraction was performed at INISA after standard salting out methods (Miller 1988). The molecular study was performed in Erlangen, Germany. The first logical step was to rule out $C Y P 1 B 1$ mutations in the PCG family and TIGR/MYOC as well as OPTN mutations in the COAG and JOAG families.

\section{PRIMARY CONGENITAL GLAUCOMA FAMILY}

The PCG family presents consanguinity and the disease follows an autosomal recessive mode of inheritance (Fig. 1). Four members of the family are affected. Two of the patients are brothers (V:8 and V:9); their parents are second cousins. The third patient (V:7) is a little bit more than a first cousin on both sides of the affected brothers (their mothers are sisters and their fathers are brothers), therefore he is also son of a consanguineous mating between second cousins. The two brothers have classical congenital glaucoma, already present at birth, with the typical signs of tearing, light sensitivity, cloudiness of the cornea, and enlargement of the eye. They have experienced several surgeries in both eyes. In contrast, their affected cousin has a milder form of the disease presenting the first symptoms at the age of 9 years old, however with the symptoms of congenital glaucoma and has not required surgery. Individual III:3 is also affected with glaucoma, though with an age of onset after the age of 50 .

The affected members of the family were screened for mutations in CYP1B1. A 10 base pair homozygous duplication (1546-1555dup TCATGCCACC) (Fig. 2.) was discovered in exon 3 of individuals V:7, V:8 and V:9. The gene was then sequenced for all available family members. Both pairs of parents of the three affected boys are heterozygous for this duplication which they inherited from their mothers (III-1 and III-4). Other members of the family, IV-1, IV-10 and V-6 are also heterozygous, as can be seen in figure 1 .

This duplication causes an early stop codon that results in a protein which is 140 amino acids shorter than the normal version. The truncated protein lacks the functionally essential heme-binding site. The mutation was 


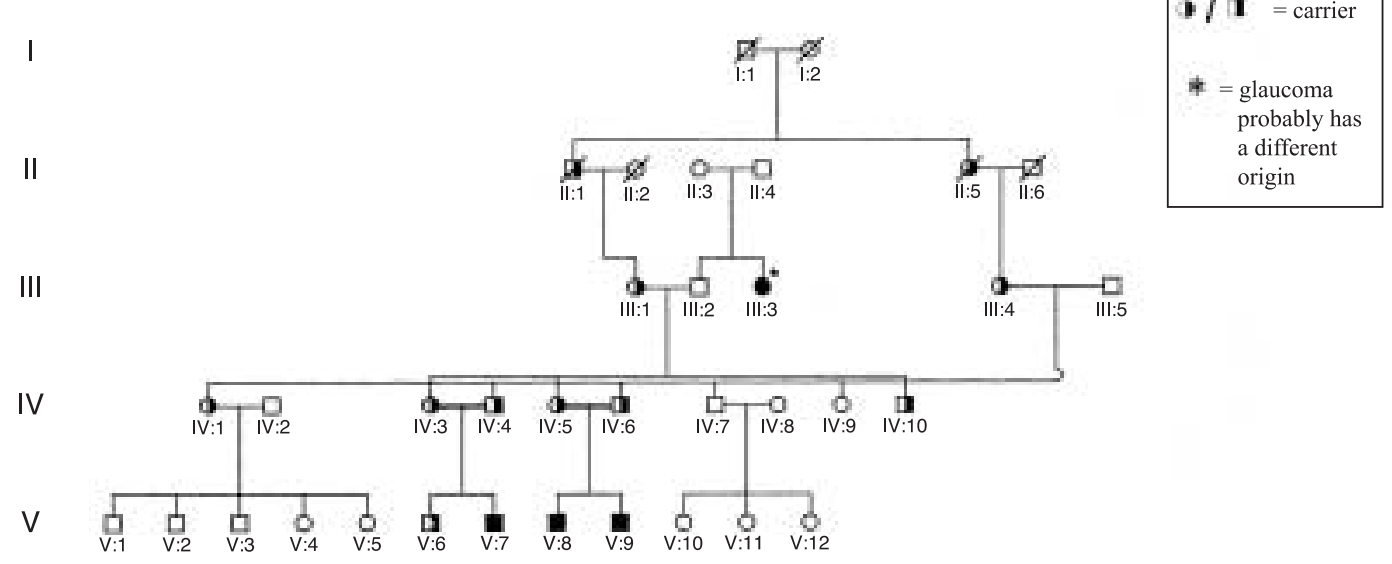

Fig. 1. Pedigree of the family with primary congenital glaucoma (PCG) due to a 1546-1555dupTCATGCCACC at the CYP1B1 gene.

first described by Stoilov et al. (1998) in patients from the USA, Turkey, and England, both in homozygous and in heterozygous state with other mutations (Trp57Cys, Arg469Trp,Gly61Glu). Michels-Rautenstrauss et al. (2001) also found it in a German patient in heterozygous form combined with a deletion (14101422delGAGTGCAGGCAGA), and Stoilov et al. (2002) have reported it in Brazilian patients both in homozygous and heterozygous form (combined with Arg368His or 8182delG).

The fact that the ten base pair duplication has been found in several ethnic groups could mean that it is an old mutation. If this is the case, the affected individuals should share a common haplotype in this region. Stoilov et al. (1997, 1998) have described six intragenic CYP1B1 single nucleotide polymorphisms (SNPs). The three affected boys in the Costa Rican family carry the haplotype 5'-C-C-GG-T-A-3' in homozygous form, which was reported to be the most common haplotype among Brazilian PCG individuals (Stoilov et al. 2002). The same haplotype was found, after studying the sequence from the compound heterozygous German patient (discussed above), which seems to support the idea that the mutation is old. The SNP data from other populations would make it possible to test this hypothesis.

Because of his different phenotype, individual V:7 was also screened for mutations in TIGR/MYOC and OPTN. No TIGR mutations were found but he has the "risk associated" (Rezaie et al. 2002) Met98Lys variant in exon 5 from OPTN. His two cousins do not present this amino acid change. It is tempting to postulate loci interaction to explain the phenotypic differences observed among him and his cousins, however recent studies show that the Met98Lys allele is equally frequent in patients and controls (Aung et al. 2003, Wiggs et al. 2003). Unknown modifier genes plus, or, environmental conditions and developmental noise have delayed the onset of the disease.

Individual III:3 does not have a mutation in any of the three screened genes. In her case, the onset of the disease occurred much later. In addition, she is the sister from the affected boys' grandfather (III:2), and the duplication 
INTERNATIONAL JOURNAL OF TROPICAL BIOLOGY AND CONSERVATION

513

A
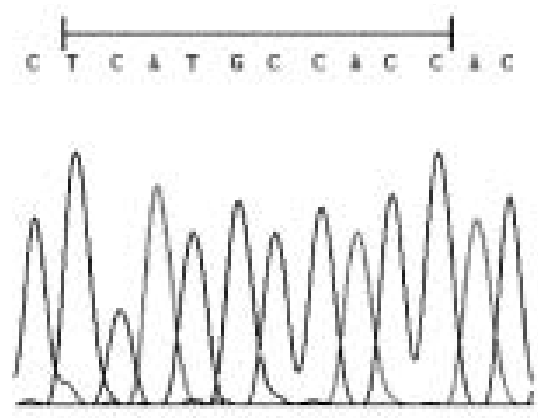

B
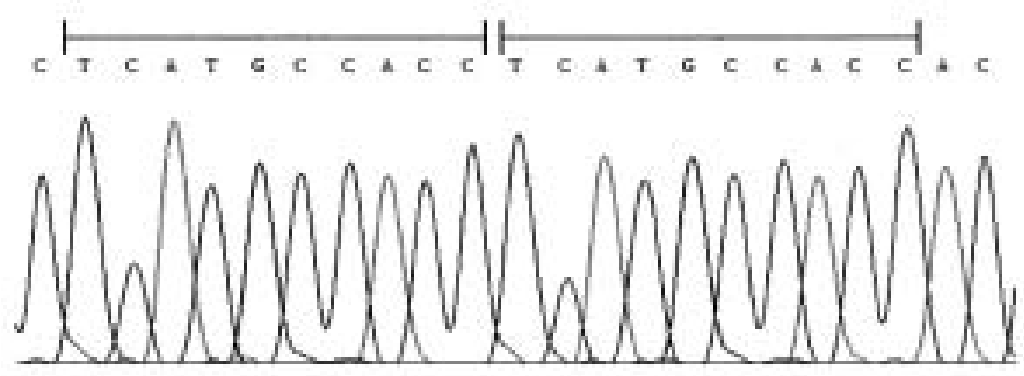

C
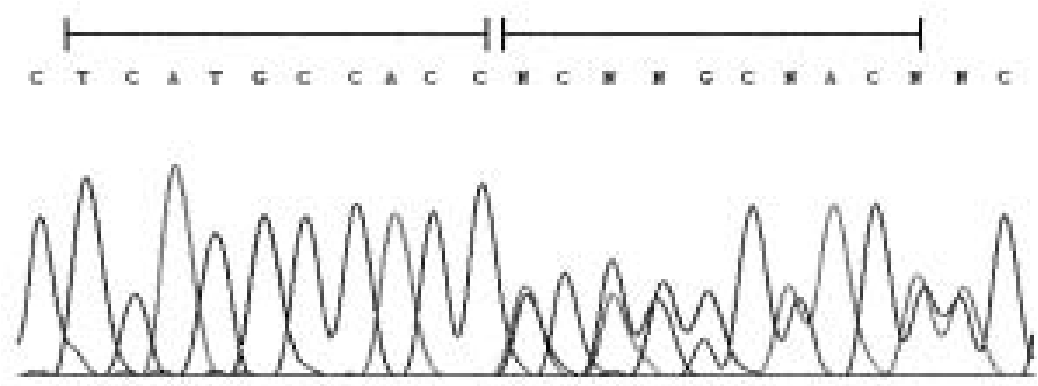

Fig. 2. Electropherograms for gene CYP1B1 in the PCG family with the duplication 15461555dupTCATGCCACC. (A) Normal sequence, (B) Homozygous duplication, (C) Heterozygous duplication. The bars on top of the sequences represent the duplicated region. The GenBank U03688 sequence was used as reference.

was not inherited from him. This suggests that III-3 surely is a sporadic case.

TIGR/MYOC and OPTN screening

TIGR/MYOC and OPTN were both inttally sequenced in one affected patient from each of the COAG families and both individuats with later onset from the PCG family, as well as in a healthy control. The Arg76Lys variant in exon 1 of the TIGR/MYOC gene was found in patients from two of the COAG families. This allele was not found in the control. The rest of the affected individuals and several healthy members from each of these families were screened for mutations in this gene to get insight on the role of this variant in the pathogenesis of the disease in these families. The Arg76Lys variant was found in 7 affected and 3 healthy persons. Reports show that this allele has often been found in glaucoma patients as well as in healthy controls (Stoilova et al. 1998, 
Fingert et al. 1999, Kubota et al. 2000, Lam et al. 2000, Shimizu et al. 2000, Mabuchi et al. 2001, Michels-Rautenstrauss et al. 2002, Forsman et al. 2003, Melki et al. 2003). Thus, it is considered an innocuous variant.

Sequencing the 13 coding exons of the OPTN gene disclosed 7 variants in the introns of the gene and 2 in the exons. The base substitutions in the introns do not interfere with splicing. The two variants in the coding sequence are, first, the Met98Lys in exon 5 only found in one individual in the PCG family (already discussed) and, second, a synonymous Thr34Thr substitution in exon 4 which with high probability does not cause the disease.

\section{LINKAGE ANALYSIS}

In summary, all of the genes known so far as involved in the pathogenesis of glaucoma can be discarded as the cause of the disease in the COAG patients of Costa Rica. Therefore, the next step was to look for other genomic regions where the responsible mutations can be found, however, only one of the seven COAG families (Fig. 3) complies with the requirements for a linkage analysis, there are affected members in three generations, with the affected individuals still alive in two of the generations, a total of eight affected persons and an autosomal dominant pattern of inheritance. A LOD score simulation revealed that a maximum value of 3.59 could be reached under ideal conditions. Thus this family was chosen for a genome scan with 379 microsatellite markers, which presented an average heterozygosity of 0,63 . The statistical analysis disclosed several regions with LOD scores "suggestive" of linkage (Chavarría-Soley 2003), which are being further evaluated with SNPs with the goal of mapping the location of the gene responsible for glaucoma in the family.

\section{GLAUCOMA IN COSTA RICA. PRELIMINARY CONCLUSIONS AND PERSPECTIVES}

The first results of the characterization of the molecular and genetic bases of glaucoma in Costa Rica allow one conclusion: glaucoma seems to have a highly heterogeneous genetic background in the country. Besides the duplication in CYPIBI (1546-1555dupTCATGCCACC) found in the Costa Rican PCG family, a mutation also reported in individuals from USA, Turkey, England, Germany and Brazil, no other known mutation has been found in any other Costa Rican familial case studied so far in genes identified elsewhere as responsible for the disease. This is a not a surprising finding. Glaucoma, especially POAG, has been shown to be a genetically heterogeneous disease. In addition, the genes involved in POAG identified so far are responsible for very few of the glaucoma cases. In large numbers of sporadic glaucoma patients the TIGR/MYOC gene is mutated in only 3 to $7.5 \%$ of the cases (Stone et al. 1997, Suzuki et

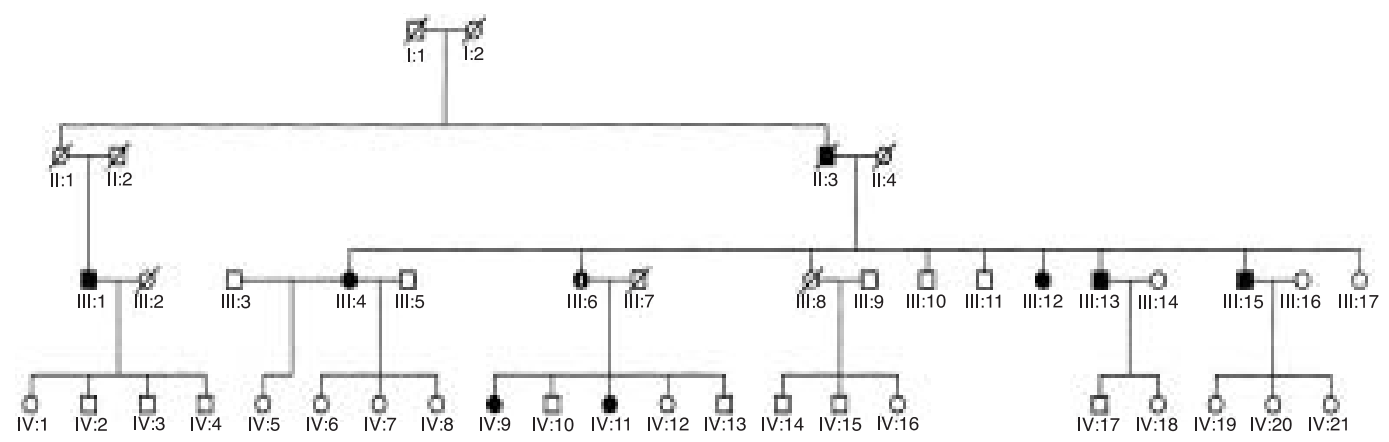

Fig. 3. Pedigree of the COAG Costa Rican family chosen for linkage analysis. 
al. 1997, Alward et al.1998, Fingert et al. 1999, Kubota et al. 2000, Shimizu et al. 2000, Michels-Rautenstrauss et al. 2002, Melki et al. 2003). The more recently identified $O P T N$ is also responsible for less than $2 \%$ of sporadic POAG cases (Aung et al. 2003, Leung et al. 2003, Wiggs et al. 2003).

Given these facts and in the context of the interethnic admixture and expansion of the Costa Rican population, it is very likely that some, maybe several, up to now unknown genes are involved in the pathology of the disease in this land. Many of these genes surely are the same causing the disease in other countries and they were introduced in Costa Rica by the interethnic gene flow process initiated during the conquest of the American continent by the Europeans. This process has delineated a Costa Rican population with a main trihybrid ancestry, resulting from the cumulative admixture of genes of European (61\%), Amerindian $(30 \%)$ and African (9\%) origin (Morera et al. 2003). The different regions of the country have a very similar hybrid structure with slight variations among them (Madrigal et al. 2001, Morera et al. 2001, 2003).

From this perspective, Costa Rica offers the opportunity to identify and characterize several genes involved in glaucoma. However, some methodological considerations must be kept in mind in order to guarantee success in the next stages of the venture. Gene mapping is a statistic-dependent process, as such relies on meeting the requirements of the method employed to estimate the significance of the association of a phenotype with a chromosomal region. The linkage analysis with the COAG family disclosed several regions where the gene responsible for glaucoma could potentially be located, but no definite linkage was found. The lack of a statistical linkage of the phenotypes with any marker, contrary to the expectations after the simulations (see above), can be due to an insufficient number of affected individuals in the family and the fact that the eight living persons suffering glaucoma are in two generations, or even a polygenic inheritance with phenocopies.

The average heterozygosity value of 0.63 showed by the set of microsatellite markers used, is lower than values from other genome scans which range from 0.76 to 0.8 (Kuokkanen et al. 1997, Lee et al. 2000, Wiltshire et al. 2001). This could reflect a reduced heterozygosity in the Costa Rican population for these microsatellites, or simply be due to the fact that the value is based on data from only 30 persons from one family. Unfortunately there is currently no information on allele-frequencies, i.e. an estimation of information content, heterozygosity, background linkage disequilibrium, etc., of the markers employed in mapping projects for the Costa Rican population. Such data, stratified by region, would permit a better marker selection for mapping efforts in the country.

The advent of a new technologies which allow the rapid typing of thousands of SNPs have made large-scale, whole-genome association studies feasible. In Costa Rica, as well as in the rest of the world, the most frequent glaucoma cases are sporadic (single, or simplex patients for which a family history is known but no other affected relatives are available). A future stage in our project would include the collection of a large group of such cases and their respective controls, which must first be screened for mutations at known glaucoma genes. If these genes are discarded as responsible of the affection, these patients and controls could be included in an association analysis using SNPs as markers. This would also require, as is the case for microsatellites, knowledge of allelic frequencies in the Costa Rican population. This knowledge would allow to determine the minimal conditions to be met by the families in linkage analyses and to estimate how suitable the Costa Rican population is for association studies, a very important subject especially in attempts to map loci involved in complex traits. In any case, the genetic study of glaucoma in Costa Rica has begun to open new research perspectives. 


\section{ACKNOWLEDGMENTS}

We thank the Deutscher Akademischer Austausch Dienst (DAAD), the Deutsche Forschungsgemeinschaft, the Gottlieb Daimler-Benz Stiftung, and the Bayerische Stiftung for their financial support. We are also grateful to Prof. Dr. med. André Reis, Director of the Institute of Human Genetics, Friedrich-Alexander University from Erlangen-Nuremberg, and to the ophthalmologists, Drs. Luis Villalobos, Bernardo Rubinstein, Paul Flikier, David Flikier, Carlos Mejía, and Christian Mardin. Our special thank is for all members of the glaucoma families in Costa Rica.

\section{RESUMEN}

El glaucoma es la segunda causa de ceguera irreversible en el mundo. El componente genético de algunos de los distintos tipos ha sido demostrado: seis loci (GLC1AGLC1F) y dos genes (TIGR/MYOC y OPTN) se conocen, hasta ahora, como responsables de la aparición de glaucomas primarios de ángulo abierto tanto del tipo juvenil (JOAG) como de 1 tipo de adultos (COAG). Además, dos loci (GLC3A,GLC3B) y un gene (CYP1B1) se han descubierto como causas del tipo primario congénito (PCG). Se presenta una relación de los estudios genéticos iniciales sobre el glaucoma en Costa Rica. Nueve familias: 1 con JOAG, 1 con PCG y 7 con COAG se estudiaron en busca de mutaciones en los genes conocidos. Una duplicación de $10 \mathrm{pb}, 1546-1555$ dupTCATGCCACC, en el gene $C Y P 1 B 1$, causa glaucoma en condición homocigota en una familia consaguínea con PCG. Esta mutación se ha encontrado en otros países y origina un codón de terminación prematuro que codifica una proteína 140 aminoácidos más corta que la normal. En dos de las familias con COAG se encontró una variante inocua Arg76Lys en el exón 1 del gen TIGR/MYOC. Otros pacientes presentaron, en el gene OPTN, dos variantes en la region codificante (Thr34Thr, Met 98Lys) y 7 cambios intrónicos. Una de las familias con COAG cumple con los requerimientos mínimos para un análisis de ligamiento, por lo que se utilizaron 379 marcadores microsatelíticos para mapear el gen causante de la enfermedad. No se obtuvieron valores LOD que claramente implicaran a alguna región cromosómica. La evidencia señala que el glaucoma hereditario en Costa Rica tiene una gran heterogeneidad genética y que es muy posible que los estudios que se desarrollan vayan a descubrir nuevos genes involucrados en la patología.

\section{REFERENCES}

Akarsu A.N., M.E. Turacli, S.G. Aktan, M. BarsoumHomsy, L. Chevrette, B.S. Sayli \& B.M. Sarfarazi. 1996. A second locus (GLC3B) for primary congenital glaucoma (Buphthalmos) maps to 1p26. Hum. Mol. Genet. 5: 1199-1203.

Alward W.L.M., J.H. Fingert, M.A. Coote, A.T. Johnson, S.F. Lerner, D. Junqua, F.J. Durcan, P.J. McCartney, D.A. Mackey, V.C. Sheffield \& E.M. Stone. 1998. Clinical features associated with mutations in the chromosome 1 open-angle glaucoma gene (GLC1A). New Eng. J. Med. 338: 1022-1027.

Bejjani B.A., R.A. Lewis, K.F. Tomey, K.L. Anderson, D.K. Dueker, M. Jabak, W.F. Astle, B. Otterud, M. Leppert \& J.R. Lupski. 1998. Mutations in CYP1B1, the gene for cytochrome P4501B1, are the predominant cause of primary congenital glaucoma in Saudi Arabia. Am. J. Hum. Genet. 62: 325-333.

Bejjani B.A., D.W. Stockton, R.A. Lewis, K.F. Tomey, D.K. Dueker, M. Jabak, W.F. Astle \& J.R. Lupski. 2000. Multiple CYP1B1 mutations and incomplete penetrance in an inbred population segregating primary congenital glaucoma suggest frequent de novo events and a dominant modifier locus. Hum. Mol. Genet. 9: 367-374.

Buhrmann, R.R., H.A. Quigley, Y. Barron, S.K. West, M.S. Oliva \& B.B.O. Mmbaga. 2000. Prevalence of Glaucoma in a Rural East African Population. Invest. Ophthalmol. \& Vis. Sci. 41: 40-48.

Caballero, M. \& T. Borras. 2001. Inefficient processing of an olfactomedin-deficient myocilin mutant: potential physiological relevance to glaucoma. Biochem. Biophys. Res. Commun. 282: 62-670.

Chavarría-Soley, G. 2003. Tamizaje de genes conocidos en familias y pacientes con glaucoma y análisis de ligamiento en una familia costarricense con glaucoma primario de ángulo abierto. Magister Scientiae Thesis. Sistema de Estudios de Posgrado, Universidad de Costa Rica, San José, Costa Rica

Chavarría Soley G., K.A. Bosse, C.Y. Mardin, G.O.H. Naumann, D. Flikier, P.Flikier, J. Azofeifa, A. Reis, K. Michels-Rautenstrauss \& B.W. Rautenstrauss. 2003. Primary Congenital Glaucoma (PCG): a novel single nucleotide deletion and varying phenotypic expression for the 1546-1555dup mutation in the GLC3A (CYP1B1) gene in two families with different ethnic origin. J. Glaucoma. 12: 27-30.

Dielemans, I., J.R. Vingerling, R.C. Wolfs, A. Hofman, D.E. Grobee \& P.T. de Jong. 1994. The prevalence 
of primary open-angle glaucoma in a populationbased study in the Netherlands. The Rotterdam Study. Ophthalmology 101: 1851-1855.

Ekstrom, C. 1996. Prevalence of open-angle glaucoma in central Sweden. The Tierp Glaucoma Survey. Acta Ophthalmol. Scand. 74: 101-112.

Faber P.W., G.T. Barnes, J. Srinidhi, J. Chen, J.F. Gusella \& M.E. MacDonald. 1998. Huntingtin interacts with a family of WW domain proteins. Hum. Mol. Genet. 7: 1463-1474.

Fingert J.H., E. Heon, J.M. Liebmann, T. Yamamoto, J.E. Craig, J. Rait, K. Kawase, S.T. Hoh, Y.M. Buys, J. Dickinson, R.R. Hockey, D. Williams-Lyn, G. Trope, Y. Kitazawa, R. Ritch, D.A. Mackey, W.L. Alward, V.C. Sheffield \& E.M. Stone. 1999. Analysis of myocilin mutations in 1703 glaucoma patients from five different populations. Hum. Mol. Genet. 8: 899-905.

Foster, P.J. \& G.J. Johnson. 2001. Glaucoma in China: how big is the problem? Br. J. Ophthalmol. 85: 1277-1282.

Forsman, E., S. Lemmelä, T. Varilo, P. Kristo, H. Forsius, E. Sankila \& I. Järvela. 2003. The role of TIGR and OPTN in Finnish glaucoma families: a clinical and molecular genetic study. Mol. Vision. 9: 217-222.

Hattula K. \& J. Peranen. 2000. FIP-2, a coiled-coil protein, links huntingtin to Rab8 and modulates cellular morphogenesis. Curr. Biol. 10: 1603.1606.

Jacobson, N., M. Andrews, A.R. Shepard, D. Nishimura, C. Searby, J.H. Fingert, G. Hageman, R. Mullins, B.L. Davidson, Y.H. Kwon, W.L. Alward, E.M. Stone, A.F. Clark \& V.C. Sheffield. 2001. Non-secretion of mutant proteins of the glaucoma gene myocilin in cultured trabecular meshwork cells and in aqueous humor. Hum. Mol. Genet. 10: 117-125.

Kitsos, G., H. Eiberg, E. Economou-Petersen, M.K. Wirtz, P.L. Kramer, M. Aspiotis, N. Tommerup, M.B. Petersen \& K. Psilas. 2001. Genetic linkage of autosomal dominant primary open angle glaucoma to chromosome $3 \mathrm{q}$ in a Greek pedigree. Eur. J. Hum. Genet. 9: 452-457.

Klaver, C.C.W., R.C.W. Wolfs, J.R. Vingerling, A. Hofman \& P.T.V.M. de Jong. 1998. Age-Specific Prevalence and Causes of Blindness and Visual Impairment in an Older Population. Arch. Ophthalmol. 116: 653-658.

Kubota, R., S. Noda, Y. Wang, S. Minoshima, S. Asakawa, J. Kudoh, Y. Mashima, Y. Oguchi, \& N. Shimizu. 1997. A novel myosin-like protein (Myocilin) expressed in connecting cilium of photoreceptor:
Molecularcloning, tissue expression. Genomics 41: 360-369.

Kubota R., Y. Mashima, O. Yuichiro, T. Tomihiko, T. Kimura, Y. Hotta, A. Kanai, S. Tokuoka, I. Azuma, H. Tanihara, M. Inatani, Y. Inoue, J. Kudoh, Y. Oguchi \& N. Shimizu. 2000. Novel mutations in the myocilin gene in Japanese glaucoma patients. Hum. Mutat.16: 270.

Kuokkanen S., M. Gschwend, J.D. Rioux, M.J. Daly, J.D. Terwillinger, P.J. Tienari, J. Wikström, J. Palo, L.D. Stein, T.J. Hudson, E.S. Lander \& L. Peltonen. 1997. Genomewide Scan for Multiple Sclerosis in Finnish Multiplex Families. Am. J. Hum. Genet. 61: 1379-1387.

Lam, D.S.C., Y.F. Leung, J.K.H. Chua, L. Baum, D.S.P. Fan, K.W. Choy \& C.P. Pang. 2000. Truncations in the TIGR gene in individuals with and without primary open-angle glaucoma. Invest. Ophthal. Vis. Sci. 41:1386-1391.

Lai, J.S.M., D.T.L. Liu, C.C.Y. Tham R.T.H. Li, \& D.S.C. Lam. 2001. Epidemiology of acute primary angleclosure glaucoma in the Hong Kong Chinese population:prospective study. HKMJ 7: 118-123.

Le, A., B.N. Mukesh, C.A. McCarty \& H.R. Taylor. 2003. Risk Factors Associated with the Incidence of OpenAngle Glaucoma: The Visual Impairment Project. Invest. Ophthal. Vis. Sci. 44: 3783-3789.

Lee, P.P., Z.W. Feldman, J. Osterman, D.S. Brown \& S.A. Sloan. 2003. Longitudinal Prevalence of Major Eye Diseases. Arch. Ophthalmol. 121: 1303-1310.

Lee Y., F. Rüschendorf, C. Windemuth, M. SchimittEgenolf, A. Stadelmann, G. Nürnberg, M. Ständer, T.F. Wienker, A. Reis \& H. Traupe. 2000. Genomewide Scan in German Families Reveals Evidence for a Novel Psoriasis-Susceptibility Locus on Chromosome 19p13. Am. J. Hum. Genet. 67: 1020-1024.

Leske, M.C., A.M. Connell, A.P. Schachat \& L. Hyman. 1994. The Barbados Eye Study. Prevalence of open angle glaucoma. Arch. Ophthalmol. 112: 821-829.

Leske, M.C., A.M. Connell, S.Y. Wu, B. Nemesure, X. Li, A.P. Schachat \& A. Hennis. 2001. Incidence of open-angle glaucoma: the Barbados Eye Studies. The Barbados Eye Studies Group. Arch. Ophthalmol. 119: 89-95.

Leung, Y.F., B.J. Fan, D.S.C. Lam, W.S. Lee, P.O.S. Tam, J.K.H. Chua, C.C.Y. Tham, J.S.M. Lai, D.S.P. Fan \& C.P. Pang. 2003. Different Optineurin Mutation Pattern in Primary Open-Angle Glaucoma. Inv. Opthalmol. \& Vis. Sci. 44: 3880-3884. 
Li, Y., J. Kang \& M.S. Horowitz. 1998. Interaction of an adenovirus E3 14.7-kilodalton protein with a novel tumor necrosis factor alpha-inducible cellular protein containing leucine zipper domains. Mol. Cell. Biol. 18: 1601-1610.

Mabuchi, F., Z. Yamagata, K. Kashiwagi, S. Tang, H. Ijima \& S. Tsukahara. 2001. Analysis of myocilin mutations in Japanese patients with normal tension glaucoma and primary open angle glaucoma. Clin Genet 59: 263-268.

Madrigal, L., B. Ware, R. Miller, G. Saenz, M. Chavez \& D. Dykes. 2001. Ethnicity, Gene Flow, and Population Subdivision in Limón, Costa Rica. Am. J. Phys. Anthrop. 114: 99-108.

Melki, R., A. Belmouden, A. Brezin \& H. Garchon. 2003. Myocilin Analysis by DHPLC in French POAG Patients: Increased Prevalence of Q368X Mutation. Hum. Mut. 22: 179.

Michels-Rautenstrauss K., C.Y. Mardin, W.M. Budde, T. Liehr, J. Polansky, T. Nguyen, V. Timmerman, C. Van Broeckhoven, G.O.H. Naumann, R.A. Pfeiffer \& B. Rautenstrauss. 1998. Juvenile open angle glaucoma: fine mapping of the TIGR gene to 1q24.3q25.2 and mutation analysis. Hum. Genet. 102: 103-106.

Michels-Rautenstrauss K.G., C.Y. Mardin, M. Zenker, G.C. Gusek-Schneider \& B.W. Rautenstrauss. 2001. Primary congenital glaucoma (PCG): three case reports on novel mutations and combinations of mutations in the GLC3A (CYP1B1) gene. J. Glaucoma 10: 354-357.

Michels-Rautenstrauss K., C. Mardin, N. Wakili, A.M. Junemann, L . Villalobos, C. Mejia, G.C. Soley, J .Azofeifa, S .Ozbey, G.O. Naumann, A .Reis \& B. Rautenstrauss. 2002. Novel mutations in the MYOC/GLC1A gene in a large group of glaucoma patients. Hum. Mutat. 20: 479-80.

Miller SA, Dykes DD \& HF. Polesky. 1988. A simple salting out procedure for extracting DNA from human nucleated cells. Nucl. Acids Res. 16: 1215.

Moreland R.J., Dresser M.E., Rodgers J.S., Roe B.A., Conaway J.W., Conaway R.C. \& J.S. Hanas. 2000. Identification of a transcription factor IIIA-interacting protein. Nucl. Acids Res. 28: 1986-1993.

Morera, B., R. Marín-Rojas \& R. Barrantes. 2001. Análisis de varios marcadores genéticos clásicos en la población de Costa Rica. Rev. Biol. Trop. 49: 1237 1252.

Morera, B., R. Barrantes \& R. Marin-Rojas. 2003. Gene Admixture in the Costa Rican Population. Ann. Hum. Genet. 67: 71-80.
Nebert, D.W., D.R. Nelson, M.J. Coon, R.W. Estabrook, R. Feyereisen, Y. Fujii-Kuriyama, F.J. Gonzalez, F.P. Guengerich, I.C. Gunsalus \& E.F. Johnson. 1991. The P450 superfamily: update on new sequences, gene mapping, and recommended nomenclature. DNA Cell. Biol. 10: 1-14.

Nemesure, B., Q. He, N. Mendell, S. Wu, J.F. Hejtmancik, A. Hennis, M.C. Leske \& Barbados Family Study Group. 2001. Inheritance of Open-Angle Glaucoma in the Barbados Family Study. Am. J. Med. Genet. 103: 36-43.

Nemesure, B., J. Xiaodong, H. Qimei, M.C. Leske, S-Y. Wu, A. Hennis , N. Mendell, J. Redman, H.J. Garchon, R. Agarwala, A.A. Schaffer, F. Hejtmancik \& Barbados Family Study Group. 2003. A genomewide scan for primary open-angle glaucoma (POAG): the Barbados Family Study of Open-Angle Glaucoma. Hum. Genet. 112: 600-609.

Polansky J.R., D.J. Fauss, P. Chen, H. Chen, E. LütjenDrecoll, D. Johnson, R.M. Kurtz, Z-D. Ma, E. Bloom \& T.D. Nguyen. 1997. Cellular pharmacology and molecular biology of the trabecular mehwork inducible glucocorticoid response gene product. Ophthalmologica 211: 126-139.

Quigley, H.A. 1996. The number of persons with glaucoma worldwide. Br. J. Ophthalmol. 80: 389-393.

Quigley, H.A., S.K. West, J. Rodríguez, B. Munoz, R. Klein \& R. Snyder. 2001. The Prevalence of Glaucoma in a Population-Based Study of Hispanic Subjects. Arch. Ophthalmol. 119: 1819-1826.

Racette, L., M.R. Wilson, L.M. Zangwill, R.N. Weinreb \& P.A. Sample. 2003. Primary Open-Angle Glaucoma in Blacks: A Review. Survey of Ophthalmology 48(3): 295-313.

Rezaie T., A. Child, R. Hitchings, G. Brice, L. Miller, M. Coca-Prados, E. Heon, T. Krupin, R. Ritch, D. Kreutzer, R.P. Crick \& M. Sarfarazi. 2002. Adultonset primary open-angle glaucoma caused by mutations in optineurin. Science 295: 1077-1079.

Rodriguez, J., R. Sanchez, B. Munoz, S.K. West, A. Broman, R.W. Snyder, R. Klein \& H. Quigley. 2002. Causes of blindness and visual impairment in a population-based sample of U.S. Hispanics. Ophthalmology 109: 737-743.

Sarfarazi M., A.N. Akarsu, A. Hossain, M.E. Ruracli, S.G. Aktan, M. Barsoum-Homsy, L. Chevrette \& B.S. Sayli. 1995. Assignment of a locus (GLC3A) for primary congenital glaucoma (Buphthalmos) to 2p21 and evidence for genetic heterogeneity. Genomics 30: 171-177.

Sarfarazi, M. 1997. Recent advances in molecular genetics of glaucomas. Hum. Molec. Genet. 6: 1667-1677. 
Sarfarazi M., A. Child, D. Stoilova, G. Brice, T. Desai, O.C. Trifan, D. Poinoosawmy \& R.P. Crick. 1998. Localization of the fourth locus (GLC1E) for adultonset primary open-angle glaucoma to the 10p15p14 region. Am. J. Hum. Genet. 62: 641-652.

Sarfarazi, M. \& I. Stoilov. 2000. Molecular genetics of primary congenital glaucoma. Eye 14: 422-428.

Schwamborn K., R. Weil, G. Courtois, S.T. Whiteside \& A. Israel. 2000. Phorbol esters and cyokines regulate the expression of the NEMO-related protein, a molecule involved in a NF-kappa-B-independent pathway. J. Biol. Chem. 275: 22780-22789.

Sheffield V.C., E. M. Stone, W.L.M. Alward, A.V. Drack, A.T. Johnson, L.M. Streb \& B.E. Nichols. 1993. Genetic linkage of familial open angle glaucoma to chromosome 1q21-q31. Nature Genet. 4: 47-50.

Shields, M., R. Ritch \& T. Krupin. 1996. Classification of the glaucomas. In Rotch R, Shields BM, Krupin T (eds.). The Glaucomas. Mosby, St. Louis, Vol 2, pp. 717-725.

Shimizu, S., P.R Lichter, T. Johnson, Z. Zhou, M. Higashi, M. Gottfredsdottir, M. Othman, S.E.Moroi, F.W. Rozsa, R.M. Schertzer, M.S. Clarke, A.L. Schwartz, C.A. Downs, D. Vollrath \& J.E. Richards. 2000. Age-dependent Prevalence of Mutations at the GLC1A Locus in Primary Open-angle Glaucoma. Am. J. Ophtal. 130: 165-177.

Shingleton, B.J., F.G. Berson, L. Cantor, E.A. Hodapp \& D.A. Lee. 1994. Glaucoma. Basic and Clinical Science Course. Section 10. American Academy of Ophtalmology, USA. 147 p.

Stoilov I, A.N. Akarsu \& M. Sarfarazi. 1997. Identification of three different truncating mutations in cytochrome P4501B1 (CYP1B1) as the principal cause of primary congenital glaucoma (Buphthalmos) in families linked to the GLC3A on chromosome 2 p21. Hum. Mol. Genet. 6: 641-647.

Stoilov I., A. Nurten, I. Aloize, A. Child, M. BarsoumHomsy, M.E. Turacli, M. Or, R.A. Lewis, N. Ozdemir, G. Brice, S.G. Aktan, L. Chevrette, M. Coca-Prados \& M. Sarfarazi 1998. Sequence analysis and homology modeling suggest that primary congenital glaucoma on $2 \mathrm{p} 21$ results from mutations disrupting either the hinge region or the conserved core structures of cytochrome P4501B1. Am. J. Hum. Genet. 62: 573-584.

Stoilov, I., I. Jansson, M. Sarfarazi \& J.B. Schenkman. 2001. Roles of cytochrome p450 in development. Drug Metabol. Drug Interact. 18: 33-55.

Stoilov, I.R., V.P. Costa, J.P., Vasconcellos, M.B. Melo, A.J. Betinjane, J.C. Carani, E.V. Oltrogge \& M.
Sarfarazi. 2002. Molecular genetics of primary congenital glaucoma in Brazil. Invest. Ophthalmol. Vis. Sci. 43: 1820-1827.

Stoilova D., A. Child, O.C. Trifan, R.P. Crick, R.L. Coakes \& M. Sarfarazi.1996. Localization of a locus (GLC1B) for adult-onset primary open angle glaucoma to the 2cen-q13 region. Genomics 36: 142-150.

Stoilova D., A. Child, G. Brice, T. Desai, M. BarsoumHomsy, N. Ozdemir, L. Chevrette, M.F. Adam, H.J. Garchon, R. Pitts Crick \& M. Sarfarazi. 1998. Novel TIGR/MYOC mutations in families with juvenile onset primary open angle glaucoma. J. Med. Genet. 35: 989-992.

Stone E.M., J.H. Fingert, W.L.M. Alward, T.D. Nguyen, J.R. Polansky \& S.L.F. Sunden 1997. Identification of a gene that causes primary open angle glaucoma. Science 175: 668-670.

Suzuki Y., S. Shirato, F. Taniguchi, K. Ohara, K. Nishimaki \& S. Ohta.1997. Mutations in the TIGR gene in familial primary open-angle glaucoma in Japan. Am. J. Hum. Genet. 61: 1202-1204.

Tamm, E.R. 2002. Myocilin and glaucoma:facts and ideas. Prog. Retin. Eye Res. 21: 395-428.

Trifan O.C., E.I. Traboulsi, D. Stoilova, I. Alozie, R. Nguyen, S. Raja \& M. Sarfarazi. 1998. The third locus (GLC1D) for adult-onset primary open-angle glaucoma maps to the $8 \mathrm{q} 23$ region. Am. J. Ophtalmol. 126: 17-28.

Wensor, M.D., C.A. McCarty, Y.L. Stanislavsky, P.M. Livingston \& H. R. Taylor. 1998. The Prevalence of Glaucoma in the Melbourne Visual Impairment Project. Ophthalmology 105: 733-739.

Wiggs J.L., R.R. Allingham, A. Hossain, J. Kern, J. Auguste, E.A. DelBono, B. Broomer, F. Lennon Graham, M. Hauser, M. Pericak-Vance \& J.L. Haines. 2000. Genome-wide scan for adult onset primary open angle glaucoma. Hum. Mol. Genet. 9: 1109-1117.

Wiggs, J.L, J. Auguste, R.R. Allingham, J.D. Flor, M.A. Pericak-Vance, K.Rogers, K.R. LaRocque, F.L. Graham, B. Broomer, E. Del Bono, J.L. Haines \& M. Hauser. 2003. Lack of Association of Mutations in Optineurin With Disease in Patients with Adult-onset Primary Open-angle Glaucoma. Ophthal. Mol. Genet. 121: 1181-1183.

Wiltshire S., A.T. Hattersley, G.A. Hitman, M. Walker, J.C. Levy, M. Sampson, S. O'Rahilly, T.M. Frayling, J.I. Bell, G.M. Lathrop, A. Bennet, R. Dhillon, C. Fletcher, C.J. Groves, E. Jones, P. Prestwich, N. Simecek, P.V.S. Rao, M. Wishart, R. Foxon, S. Howell, D. Smedley, L.R. Cardon, S. Menzel \& M.I. 
McCarthy. 2001. A Genomewide Scan for Loci Predisposing to Type 2 Diabetes in a U.K. Population (The Diabetes UK Warren 2 Repository): Analysis of 573 Pedigrees Provides Independent Replication of a Susceptibility Locus on Chromosome 1q. Am. J. Hum. Genet. 69: 553-569.

Wirtz M.K., J.R. Samples, P.L. Kramer, K. Rust, J.R. Topinka, J. Yount, R.D. Koler \& T.S. Acott. 1997. Mapping of gene for adult-onset primary open-angle glaucoma to chromosome 3q. Am. J. Hum. Genet. 60: 296-394.

Wirtz M.K., J.R. Samples, K. Rust, J. Lie, L. Nordling, K. Schilling, T.S. Acott \& P.L. Kramer. 1999. GLC1F, a new primary open-angle glaucoma locus, maps to 7q35-q36. Arch. Ophthalmol. 117: 237-241.

Wolfs, R.C.W., C.C.W. Klaver, R.S. Ramrattan, C.M. van Duijn, A. Hofman \& P.T.V.M de Jong. 1998. Genetic Risk of Primary Open-angle Glaucoma. Opht. Mol. Genet. 116: 1640-1645

\section{INTERNET REFERENCES}

Aung, T., N.D. Ebenezer, G. Brice, A.H. Child, Q. Prescott, O.J.Lehmann, R.A. Hitchings \& S.S. Bhattacharya. 2003. Prevalence of optineurin sequence variants in adult primary open angle glaucoma: implications for diagnostic testing. J. Med. Genet. 40(8):e101. Online mutation report. USA (Downlowded: March 09, 2003, http: //www.jmedgenet.com/cgi/content/full/ 40/8/e101).

OMIM. 2004. Online Mendelian Inheritance in man. Johns Hopkins University. Baltimore. (Downloaded: March 09, 2003, http://www3.ncbi.nlm.nih.gov/omim/).

GenBank. 2004. National Center for Biotechnolgy Information. U.S. National Library of Medicine. Accession number: U03688. (Downloaded: March 09, 2003 http://www.ncbi.nlm.nih.gov/entrez/). 